\title{
THE (IN)VISIBILITY OF THE FACELESS WOMEN: ETHICS AND POLITICS ON THE PHOTOGRAPHIC IMAGES BY TERESA MARgOLLES
}

\author{
Ângela Marques \& Angie Biondi
}

\begin{abstract}
In the opposite side of these moralizing pictures produced by traditional journalistic and photojournalistic narratives, the Mexican artist Teresa Margolles creates art works that disclose the vulnerable condition of women in the brutality of serial murders in order to connect individual suffering to a collective ethics of responsibility. In this text, the analytical work focuses on two of Margolles recent art works: La búsqueda (2014) and Pesquisas (2016). Taking the concepts of vulnerability and precariousness (Butler, 2006; Butler et al., 2016), we argue that the relation between violence and gender in Margolles's art work is presented as resistance addressing a common as polemical public space (Rancière, 2004), and giving place to the possibility of an interpellation scene (Butler, 2015). We also consider that this photographic work, which articulates individual sufferings in a complex narrative capable to invite spectators to a careful and reflexive contemplation, give rise to a political and aesthetical gesture that can be related to a politics of the images as it is argued by Jacques Rancière (2010b) and Georges Didi-Huberman (2012). The political and aesthetical dynamics crossing Margolles photographs is also related to the ethical responsibility voiced by Emmanuel Levinas (1982) concept of face.
\end{abstract}

KeYwORDS

Femicide; image; vulnerability; politics of aesthetics; face

\begin{abstract}
RESUMo
$\mathrm{Na}$ contramão dos quadros morais produzidos pelos discursos fotojornalísticos tradicionais e pela cobertura mediática dos casos de femicídio no cotidiano, a artista mexicana Teresa Margolles cria obras onde a brutalidade de assassinatos em série conecta o sofrimento individual a uma responsabilidade ética coletiva. Neste texto, analisaremos as construções fotográficas de duas obras recentes da artista mexicana: La búsqueda (2014) e Pesquisas (2016). A partir das noções de vulnerabilidade e de precariedade (Butler, 2006; Butler et al., 2016), argumentamos que a relação entre violência e gênero no trabalho de Margolles é apresentada sob a forma da resistência, dirigindo-se a um comum enquanto espaço público polémico (Rancière, 2004), e instaurando a possibilidade de uma cena de interpelação (Butler, 2015). Consideramos ainda que estas obras, onde os sofrimentos individuais foram articulados em uma narrativa complexa, passíveis de interpelar os espectadores, compõem um gesto estético-político, que se acorda com a política das imagens reivindicada por pensadores como Jacques Rancière (2010b) e Georges Didi-Huberman (2012). A dinâmica política e estética que atravessa as fotografias de Margolles é relacionada ainda com a responsabilidade ética implícita na noção de rosto em Emmanuel Levinas (1982).
\end{abstract}




\section{INTRODUCTION}

It would be a mistake to think that it is only a question of finding the true and fair image for a certain reality to be transmitted. Reality is not transmitted by what an image represents, but by the challenge that reality itself constitutes for representation. (Butler, 2006, p. 182)

According to Ana Carcedo (2010, p. 28), in a major survey on femicide in Central America, violence against women in Juarez (Chihuahua State, Mexico) presents two types of messages: a vertical one, in which perpetrators reiterate male domination over the life or death of local women; and a horizontal one, where men use femicide as a strategy to demarcate territories of power (and business). The latter is very evident in the numerous recorded cases of female aggression and death as a form of revenge against rival groups. Both reiterate female subordination.

The research also points out how women in Juarez are exposed to a complex web of violent agents, including institutionalized spaces (State, family, police and media) and parallel powers such as trafficking and armed militias. There is a continuous process of violence against women that is not limited to isolated cases, crimes of passion or proximity. It is striking that femicide is reported by the newspapers in order to particularize the crimes, as if there was no relationship between them. In addition, the voices that report them are always male (police officers, journalists, investigative agents, etc.), and end up reinforcing the justifications presented by the aggressors, even though they have reservations about the brutality of the acts committed.

Caldeira (2017) emphasizes how the murdering of women gains visibility in the newspapers, that victim and aggressor appear in sealed places, without an effort from the journalistic text to register the specificities of their relations. As a result, deaths are individualized and the narratives reinforce stereotypes that blame women and obscure the responsibility of perpetrators. According to the author, women are forced to foresee their own murder and move away from the aggressor, but journalism does not ask if that woman was able to leave the relationship. That is, there is almost no reflection on the conditions in which the choices and actions of these women are defined and thus there is the erasure of asymmetries of power, inequalities and injustices of all kinds. There are no inquiries about the material and symbolic resources available in the process in which women make themselves the subjects of their lives (Blay, 2008). Such resources would enable women to exercise autonomy, to define life projects even if one considers the constraints of power, economic, social, and historical limitations and the asymmetries that limit (and thus define) the possibilities of action and the action of these women victims of violence in concert with other individuals (Biroli, 2016).

It is within this context of constraints and limitations that the women of Juarez make choices, elaborate, experience ways of life that result from a mixture between what they want and what they can and should be doing. Nor can we forget that criminal life is also defined as a possibility for the women of Juarez'.

\footnotetext{
' In Juarez crime intertwines "drug dealers, guns and people, money launderers, bodyguards, gunmen and the new muses of an exhibitionist fight: the gunslingers. To become a famous killer like La Guera Loca, accused of dozens of murders and
} 
In this sense, what Blay (2008), Carcedo (2010) and Caldeira (2017) point out is that journalism and its narratives construct a collective memory of the deaths of women: they produce a collective wound from an individual wound, but this memory often results in new death and silencing of women, since the particularized murder almost reiterates the blame on the woman alone. It is possible to argue that this is a paradoxical process of invisibility that comes into being through visibility. The preferential media framing employed in the conversion of those deaths into narratives is composed by shared hierarchical collective values that define the potential social esteem addressed to aggressors and victims. This common horizon serves as a background stage to the elaboration of recognition or devaluation criteria used to establish which subjects and ways of life are to be positively judged (Butler, 2011). In such a process invisibility has little to do with physical absence, for what matters is individuals' social and communicative inexistence. Murdered women do not speak because their voices are not heard: they do not call other people into account; they are not answered and are not recognized as morally worth of dignity. The inexistence of these women as positively valued interlocutors and the destitution of their authority and moral legitimacy to be part of a public dialogue are the two main traces of their social invisibility and ostracism.

Contrary to the silencing produced by the traditional journalistic and photojournalistic discourse (which often becomes an accomplice and agent of violence - see Picado, 2014), Mexican artist Teresa Margolles has created an installation art panel that reveals the brutality of serial killings of women where it's not the singular and reported suffering that counts, but the value of the trauma that accompanies the events and victims that these events will allow to qualify itself.

In La búsqueda (2014) and Pesquisas (2016), whose images are the object of reflection in this text, the artist presents large panels formed by glass plates on a black background with posters that search for information on missing women in the city of Juarez, In Mexico. She does not present any news, documents or records on the whereabouts of these women, but makes the installation a kind of obituary of femicide ${ }^{2}$.

Starting from this contrast between the traditional journalistic discourse and the works of La búsqueda (2014) and Pesquisas (2016) by the Mexican artist Teresa Margolles, this article takes as its red line three dimensions of the relation between visibility and invisibility that are explored in its main sections: a) the tension between silence and speech as an origin of "vulnerabilities" and "precariousness" of the subjects as interlocutors worthy of consideration and careful listen in a "scene of interpellation" (Butler, 2015); b); the tension between sensible ${ }^{3}$ and visible, and between aesthetics and politics

filmed while beheading a victim, is what some poor and fearful girls dream of when they initially enlist as "messengers", the lower echelon in the criminal pyramid, from where they can rise to positions, until they become "bobcats" and "condors." They are said to kill more coldly than their male counterparts, who are more professional and not driven by any erotic drive they would have: what motivates them is solely the goal of making money and climbing the mafia structure" (Pignotti, 2012).

2 The Center for Research and Higher Studies in Social Anthropology (CIESAS) in Mexico has investigated femicide in Ciudad Juarez since 1998. Since then, the Center has denounced the high rates of violence against women in the city, reiterating the peculiar brutality of the cases recorded.

${ }^{3}$ We consider that the sensible can not be reduced to the visible, for the sensible is what establishes the unequal division of recognition and consideration among subjects. Therefore is not possible to see or to unregister the sensible even if it 
that characterizes the possibilities of resistance in photographic images and that will be mainly approached following the thought of Jacques Rancière and Didi-Huberman; c) the tension between the human face and the Levinasian's face which is comprehended as an agonic clamor of suffering, as a speech that interpellates and calls to the ethical responsibility (Levinas, 1982; Agamben, 2000, Biondi \& Marques, 2016).

\section{Between images: La Busqueda and Pesquisas}

The work of Teresa Margolles, in some way, always dialogues with death, more specifically, with the material vestiges that comprise it: a piece of the tongue of a murdered drug user (Lengua, 2000), the fragment of a wall studded of bullets by the war of traffic (Frontera, 2010), the remains of the water used to wash corpses (Enel Aire, 2003), among others. In La búsqueda (2014), Margolles is interested in the traces related to the disappearance of women victims of murder: in transporting the remains of posters to the exhibition room of a museum, she emphasizes the effect of time and urban interventions on these pieces, ensuring the creation of a memory from the vestiges.
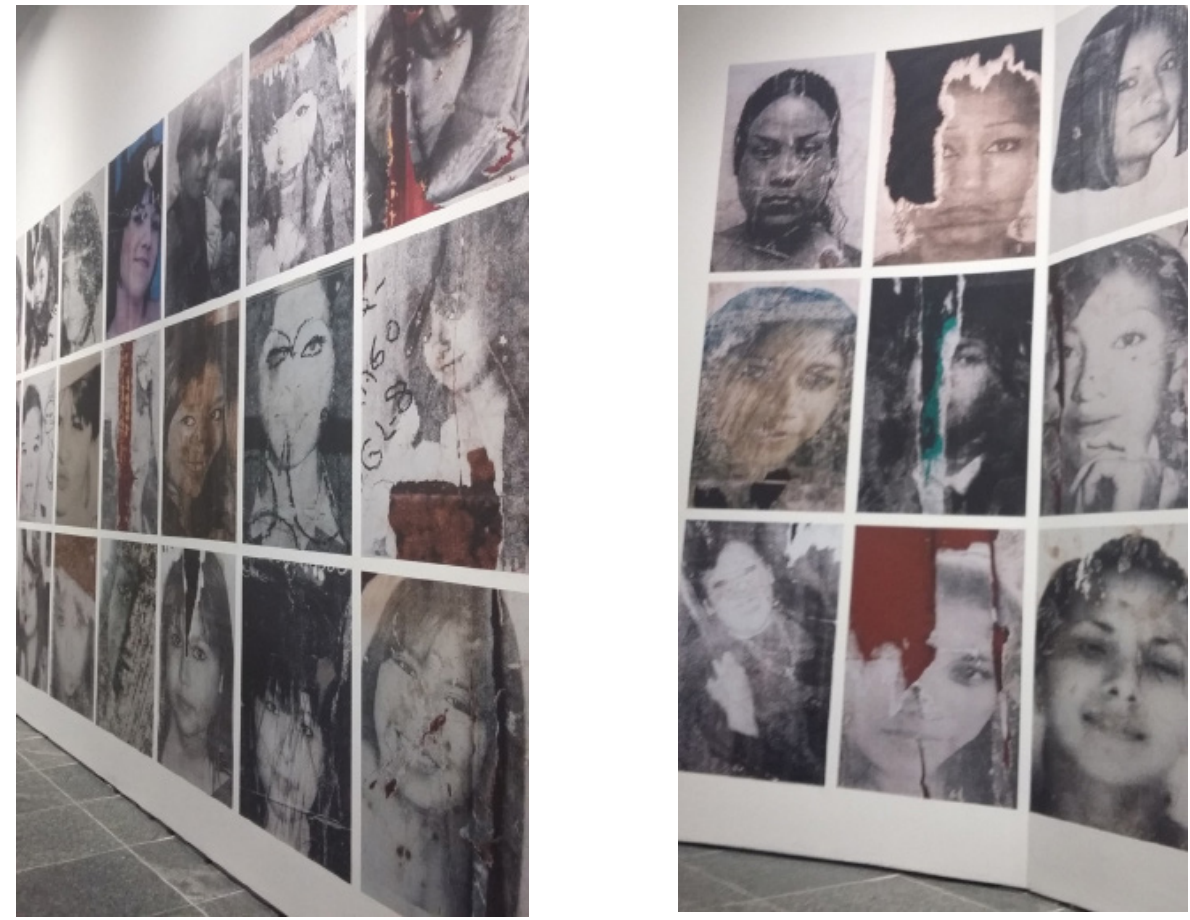

articulates social and media framings, norms and codes that organize and control collective life. We take for granted the fact that the politics of aesthetics (Rancière, 2012) is intrinsically linked to the way in that semantic and imagetic operations creates regimes of visibility capable to regulate and constraint the "appearance" of political subjects. The politics of aesthetics can furthermore regulate the distance between spectators and art works in order to avoid a confuse continuum that keep away every possibility to recognize alterity and unfamiliarity. 

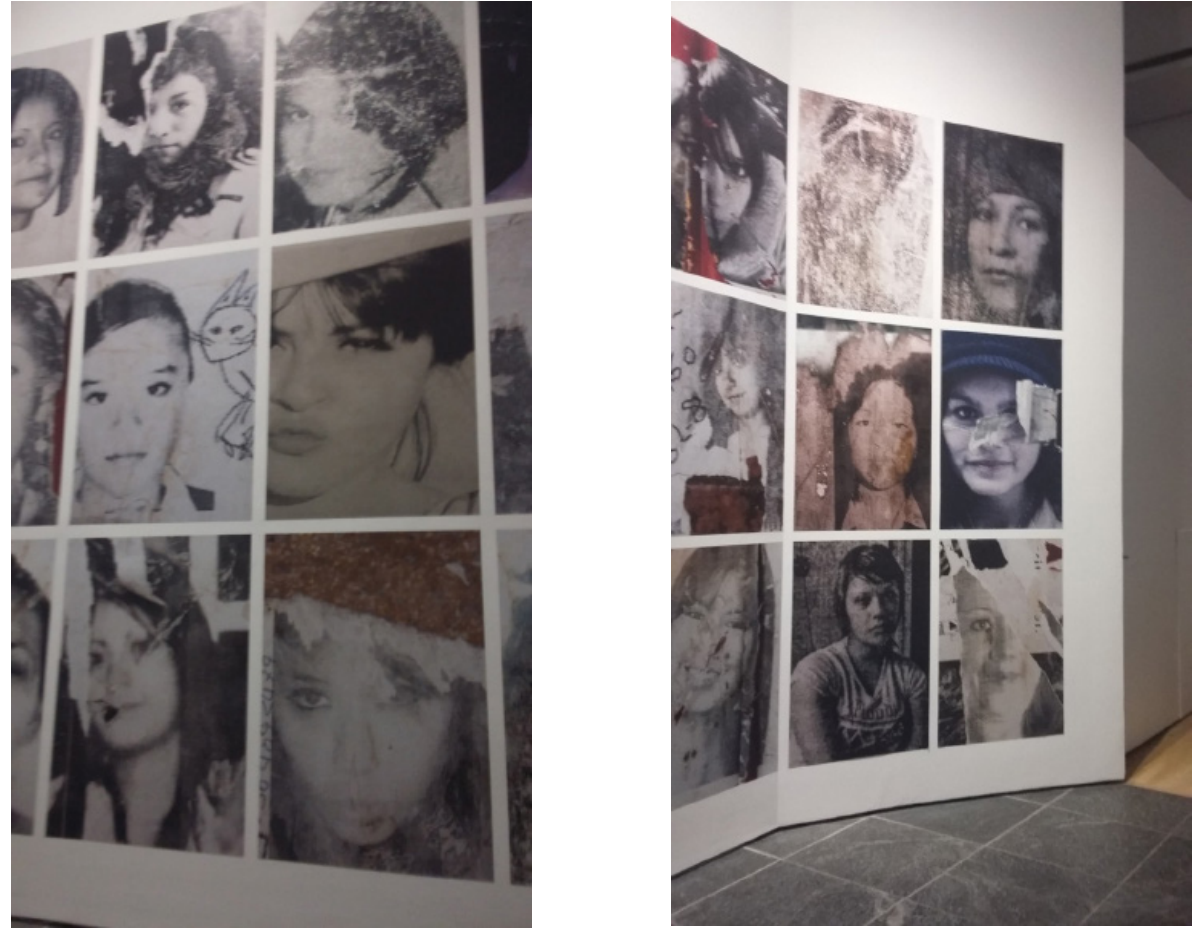

Figure 1: Pesquisas, Teresa Margolles, 2016, Exhibition Mundos, Musée d'Art Contemporain de Montréal, March, 2017

Credits: Photography by Angie Biondi

The posters that integrate the installation are so common that they become part of the city's landscape, diluting themselves in the architecture and becoming naturalized by the look. The people who passed through them should rarely reflect on the fate of the women they look for: their faces disappear and, from a memory, they become an ornament on the walls of Juarez; from a search to the forgetting and erasing of their stories.

In the set pieces it is possible to see the photographs of the victims, all dated in a recent period to the exhibition. The windows that make up the panels come from the windows of the city's shops where various requests and appeals for any information about the disappearance of these women were placed.

Faced with the notorious reality of violence against women registered in the Mexican city, it does not seem necessary to present any more news or statistical data that indicate death as the greatest probability of these disappearances. The documented existence of these young women is seen only in the poster photographs, affixed to these pieces of paper already worn out by time, dirty, some scrawled, others crushed by excess glue, torn and dividing glass space with innumerable other posters and all kinds of pamphlets.

As the visitor crosses the corridor with the feeling of being watched by the numerous glimpses that remain of these faces, he hears the reproduction of the audio of a train as if passing through a street, until it disappears down the corridor, intensifying even more the presence of that piece of real space of the city. The feeling of morbidity is growing and provocative. 
These same materials were used by the artist to compose another work, essentially photographic. Pesquisas, from 2016, is composed of the same images taken from the posters of the "disappeared" women. In this work, Margolles enlarges the faces of the women whose pictures had been used to make the La Busca prints and, with them, composes large murals with about 30 photographs (Figure 1).

The large format and layout of the long-panel photos in the corridors of the gallery emphasize the magnified dimensions of these faces, ascribes magnitude to the biography of each of the victims, although expressed there by a few traces and traces. It is a great glimpse of these women who seek the looks of so many others who walk among the corridors. It is not Margolles who inquires or questions, but the eyes of those faces and lives there that we know, already gone and victimized.

\section{TOWARDS A SPACE OF INTERPELLATION: BETWEEN PRECARIOUSNESS AND VULNERABILITY}

In this article, we argue that the central relationship between violence and gender in Teresa Margolles' photographs is not confined to the results of an aggression, to offer a battered face, a bullet and misshapen body, or to prove, by bruising and bleeding, that violence would legitimize a place for women as victims in the way journalism, among other media regimes, do. The enunciative gesture, both poetic and political, in Margolles' photographs is not restricted to making and sharing a record, but also seeks to promote an interpellation and to open a polemic space, provoking a rupture with the conformations of the discursive pictures about the image of a victim, occupied here by women who disappeared and were murdered in the city of Juarez, known for its high rates of femicide since the 1990s.

In our view, when we are concerned not only with describing how representation is constituted in an image, but also investigating the social, historical, cultural relations and ideologies that perpetuate such representation, we come to inquire about how some tacit norms operate to make certain subjects recognizable and make others decidedly harder to recognize. The problem when addressing the relationship between violence and gender, according to Butler "is not only knowing how to include more people in existing norms, but considering how existing norms attribute recognition in a differentiated way" (2015, p.2 o). In this dependence would be conjugated the conditions of precariousness and vulnerability.

In this case, it is possible to observe that the precariousness of life can manifest itself mainly in the way spaces of appearance, often marked by images and mediatic contexts, producing different ways of distributing vulnerability, causing some populations and groups to be more subject to violence than others. In these spaces of appearance, those who remain without face, or whose faces are presented as symbols of inferiority, subordination, are generally not considered worthy of recognition.

Butler states that "if recognition characterizes an act, a practice or even a scene between subjects, then the condition of being recognized characterizes the more general conditions that prepare or shape a subject for recognition" (2015, p. 19). Thus, it is 
extremely important to know the terms, conventions and general norms that act in the production of framings in order to shape an individual into a recognizable subject.

We know, according to Butler $(2006,2011)$, that vulnerability and precariousness are interdependent, but there are both conceptual and pragmatic differences in their meanings. Vulnerability is often associated with victimization or an inability to act. It is important to look at how vulnerability and protection discourses label individuals and groups as vulnerable and whether this leads to discrimination, stereotyping and undesirable paternalistic interventions. In that sense, a person can be considered vulnerable in that he/she is not in a position to prevent occurrences that would undermine what he/ she thinks is important to him/her.

Vulnerability, for Butler (2006), connects to a question of effective control, or the balance between one's power to conduct one's life and the forces influencing it. The conditions in which people make choices and make decisions, the contexts and asymmetries of power that permeate them, as well as the tactics to link with the constraints and barriers are essential to understand vulnerability not as an innate biological condition or as a "lack", a neglect and annulment of individual and collective agency, but as an opening to the negotiated construction of oneself and of life projects. How people develop projects and objectives, identifying, anticipating and confronting oppressive forces puts vulnerability in touch with the notions of autonomy and resistance.

In this respect, Butler et al. (2016) emphasizes a definition of vulnerability far from a subjective disposition or characteristic, or even an existential condition. For the authors, vulnerability names a set of relationships with a field of objects, forces, vital processes, institutions and beings that affect us and affect us in some way. The vulnerability thus understood is between our passibility (we are affected) and our agency capacity. Faced with the relationships that shape vulnerability, we have different modalities and degrees of passibility and response, which operate together, implying our political body.

In Margolles photographs, women are social individuals conditioned by their double condition. Their physical vulnerability - declared, denounced - would also reveal the vulnerability of the subject, of women, who seek to assert themselves, even as victims, legitimate and recognized, in the eyes of the other. Their faces and their lives are placed in these photographic works in order to function as a summons, a call, an appeal to their existence and condition. The vulnerability of the subject and the image is urgent when looking. At the same time, their condition is precarious since their lives don't belong to them. According to Butler, "precarious life is the condition of existing under a condition politically induced, in which certain populations suffer with deficient social and economic nets of support and remain differently exposed to violence, violations and death" (2015, p. 46).

Therefore, in our view, Margolles' pictures seek to perceive modes of vulnerability that inform ways of resistance, questioning frameworks that refuse forms of political agency developed in conditions of harshness by women victims of violence. It transforms vulnerability into deliberate exposure to the power and strangeness of the spectator in order to build political resistance as a bodily act. Here, vulnerability meets precariousness, 
since it is the condition of vulnerability that reminds us (and vice versa), according to Butler (2011), that we are all precarious subjects, since we depend on other anonymous ones to be apprehended, considered recognized. We are vulnerable and therefore we are precarious. This interdependence would be the condition of precariousness and vulnerability conjugated, especially when it is attributed to the crimes of gender.

Thus, if journalism tends to reveal individual and localized traumas in order to explore an emotional impact on the readers, we can say that Margolles, on the other hand, is interested in the traumatisms 4 that connect individual suffering to the common thread, to the possibility, with their work, of building a statement and establish the possibility of a "scene of interpellation" (Butler, 2015) for these women. The enunciation game that emerges in this scene presents the moral and visible forces that act in the discursive production of the subject engaged with others, i.e. the "ensemble of norms and rules that a subject has to negotiate in a vital and reflexive manner" (Butler, 2015, p. 21). The scene of interpellation is the intervening dimension in which we address each other preserving differences and building a common space by the proximity experience of community.

Journalistic images and narratives about gender crime often fail to transform the trauma that evolves violent death into a collectively experienced trauma, creating solidarity through pain. In other words, by using their background of shared senses, journalism often fails to create a "common thread", that is an empty space in which we perform reciprocity by carefully listen and welcoming alterity without effacing distances and differences (Mondzain, 2011). The common rarely emerges in media framing as it tends to produce victims whose lives exemplify behaviors considered inadequate and with condemnable behaviors.

The common is by us conceived as the space of exposition and appearance of the gaps and intervals that rend possible a collective action by language use. This language act promotes not only ways of "being in common" (which frequently effaces or suppress differences and singularities), but also ways of "appear in common" (Tassin, 2004). Here is a central question: the "common" of a community refers to the subjects "appearance" and to their faces' emergence on the sphere of public visibility both as moral valid interlocutors and as subjects that live a life judged as worthy of respect and esteem. Appear is to talk, to gain public existence as interlocutor, to have a face (Levinas, 1982) and to be able of interpellate the others, in a polemical public space drawn by the dissent (Rancière, 2004).

According to Rancière (2004), the creation of a common opposes a consensual space and a polemical space: it gives visibility to subjects and speeches that were not considered or listened. It is a process that bring into being the sensible experience of

\footnotetext{
4 The difference between trauma and traumatism appears in the reflections of Didier Fassin $(2007,2014)$. According to him, the trauma is linked to the emotion associated with intolerable suffering. The hurt, traumatic memory reflects the pain that attests to the reality of the event. Traumatism is associated with a collective memory of intolerable events and images. Thus trauma, when it accesses pain and connects it to a collective, produces a potent event, the traumatism. And it is the traumatism that, according to Fassin, can provide resources against victimization by making the victim the protagonist of its own speeches.
} 
voices, bodies and testimonies that were not comprehended as part of the egalitarian regime. Consensual community establish a wrong that must be treated in a polemical public space when resist to register those voices, testimonies and bodies as potential interlocutors. "This procedure creates a community of division in the two senses of the term: a space that presupposes the sharing of the same reason, but also a space which integrity only exists by the means of a division" (Rancière, 2004, p. 166).

In conclusion, the victims in Margolles' work acquire a resilient presentation and "appearance": individual sufferings were organized and articulated in a complex narrative, capable of being expressed publicly and ethically challenging viewers and demanding their attention, interpretation, and listening. The enunciation scene that she created through the photographs of $L a$ búsqueda elaborates the traumatism that, on the one hand, confers the word (the images in the installation have a "voice") to those who suffer (suffered) and presents victims with agency (opposed to passivity and inaction): they are able, in their vulnerability, to offer clues of their daily life, to recount glimpses of their existences, the violence suffered and the humiliations, insecurities and uncertainties surrounding them. There are images that put into question the naturalized perception of the "common" of a community and the ways of sensible apprehension and social recognition of marginalized subjects.

\section{TOWARDS A POLITICS OF IMAGE: VISIBILITY AND INVISIBILITY}

What else needs to be done to warn about the daily violence that slaughters, even annihilates, thousands of women every year? The works of the Mexican artist Teresa Margolles seek to trace another way to establish a relation between the image, the reality and the look. If they cannot be classified as purely artistic photographs, they cannot be classified as police or journalistic photographs either. The works of Margolles propose images outside the genres and intersect criminalistics, testimony, statistics, sociology, art. Another possible way to deal with the provocation of the works is to look at the gesture of the artist according to a politics of the image. From the critique of the Westernized logic of everything to show and to see everything from the images that populate everyday life, the images of Margolles at stake here propose to go another way: exposing the paradoxical production of visibility as invisibility.

In key texts that have been used in many discussions about image within the arts and even mediated communication (Rancière, 2009, 2010; Didi-Huberman, 2008), it is often mentioned the need to restore a debate where visibility is first and foremost the revelation of ways of doing and ways of thinking the image, including the production of its invisibility. If an access to the realities of the world seems to us increasingly and almost instantaneously, given the sophistication of the technological devices of online image capture and diffusion, on the other hand very little is revealed about the condition in which they are seen. In this sense, the proliferation of gestures to capture the world in images would reveal its paradoxical basis: overexposure leads to underexposure. In this text, we ask whether the innumerable violence and deaths of women, when registered by 
the journalistic, police or statistical headings, are not also suffering from invisibility. In the opposite side of the proliferation of images of victims that circulate across diverse media vehicles, the art work of Margolles is made of ordinary materials of quotidian life. To make this detour of the regard allows us to understand the distinction between the representative regime - which configures the content of a visible image -, and the aesthetic regime in which the image will be integrated (the sayable image) and where it moves (Rancière, 2010b).

According to Didi-Huberman (2008), the image demands from us the action of a tightrope walker, once we position ourselves, through the gaze, between the ethical space of implication and explanation (criticism, comparison, assembly). Both for him and for Rancière (2007) we are not before the images, but between them, and this requires a position: an implication in the image (movement of appropriation, of knowledge and simultaneously of self-constitution) to approach the Other.

The way of Didi-Huberman and Rancière, either convening explicitly or implicitly Walter Benjamin, characterize the montage operation realized amongst images and between them and other textual elements help us to understand the ethical and political gesture made by Margolles. The montage in Didi-Huberman (2012) allows the emergence of a historical text organized not by a chronological linearity, but under the sign of a dialectical bond between past and present. Besides it allows the questioning of dominating narratives producing a new proposition that interrupt the anterior in a endlessness process of destitution and restitution, welcoming the emergence of the difference. This elaboration demands the gesture of "welcoming the discontinuity of the history, interrupting the chronological and smoothie time, renouncing to a happy development of a flap and non fractured syntax" (Didi-Huberman, 2012, p. 99).

Rancière (2012) also highlights this dialectical aspect of montage in which it relates heterogeneous elements producing unfamiliarity in opposition to what he calls symbolic montage. This kind of montage has the effect of harmonize and articulate images of violence and rebellion proposing a type of sensible and consensual community which identifies itself by familiarity with exposed elements. In the symbolic montage the spectator, in spite of putting into relation very different materials, is too close to the images and identify himself with them, becoming incapable of distinguish the lacks, the excesses and the gaps that configure the common of a community. The dialectical montage otherwise build barriers and distances between representation and public allowing a rupture in the continuum pretended to exist between passibility (activation of emotions) and a practical action of intervention. In this case, the politicity of the montage is less related to an activation of the pathos and of consciousness (given the artist intention) and more linked to the manner of conjugating movement and restless, voice and silence.

In Margolles works, even as remains of a substance, the characters exist, and, being assembled in a dialectic montage, they present themselves and demand a gaze and a position from the one who looks. And here, fixed as an image, as a kind of ghostly or spectral presence, they show a world reality that persists, despite the many disappearances of their lives. "Janete Esparza, Patricia Iharra, Nancy Navarro ..." Each of these 
feminine faces with their singular traits and looks has a history, a name, a life. However, no matter what their particular existence has been, they all come together for the same purpose and share, in the same way, gender crime.

Margolles' photographs seem to prolong the search. However, they are now looking for the viewer and, by another route, through another means of representation that is not mediatized, journalistic, but that of the poetics - and politics - that indicate other ways of exposing the other in their reality. It seeks, therefore, to move from the commonplace of formatted, framed and homogeneous images to provoke other do-see and do-know relationships.

At this point, one is directly confronted with a media logic responsible for the management and production of the (in)visibilities that certain subjects, such as women, assume in the contemporary world, especially in the many cities that could replicate the situation at Juarez. La Búsqueda encourages us to imagine the life and death of these women from the fragments and flashes of surviving images.

The act of imagining requires of us a difficult ethics of the image: neither the invisible par excellence, nor the icon of the horror, nor the simple document. A simple image: inadequate, but necessary; inexact but true. The image is here the eye of history: its tenacious vocation to make visible. But it is also in the eye of history: in a local zone, in a moment of visual suspense, as in the eye of a cyclone. (Didi-Huberman, 2003, p. 56)

A surviving image is one that, according to Didi-Huberman $(2008,2011)$, refuses to reveal everything, that resists the pressure of total visibility, exposing the spotlight that imposes a radical imperative of publicity, imposes violence on the subjects/objects portrayed and also on the viewer. In order to survive, the images should not obscure, but rather guard the darkness, as a welcoming invitation to the long contemplation (the calm and seductive eye of a hurricane, embraced by destruction), which slows down time in the name of the emergence of the relationship, of experience of affectation.

Thus, different types of relationships define the images, those that are established inside and outside the artistic scope, which preconfigure statements, which set up and dismantle relations between the visible and the invisible, the sayable and the silent. As Rancière says, "the image is not simply the visible. It is the device through which this visible is captured" (2007, p. 199) and the modes of its capture.

The representation is not the act of producing a visible form, it is rather the act of giving an equivalent, something that the word does as much as the photograph. The image is not the double of an object. It is a complex game of relations between the visible and the invisible, between the visible and the word, between the said and the not-said. (...) It is the voice of a body that transforms a sensitive event into another, striving to make us 'see' what this body saw, by making us see what it tells us. (Rancière, 2010, p. 139)

This is where visibility is a political issue. The politics of images is intrinsically linked to how operations in the images constitute the regimes of visibility capable of regulating 
and constraining the "appearance" and exposition of subjects, as well as constructing regulations for the viewer's distance. It is important to emphasize that Margolles' installations question the absence of distance between the posters and citizens, between the photojournalistic images and the place of the spectator, promoting a form of violence that blends spaces and bodies to the point of erasing any possibility of estrangement and emergency of difference.

The problem is not whether or not to show the horrors suffered by the victims of this or that violence. Rather, it concerns the construction of the victim as an element of a certain distribution of the visible. An image is never alone. It belongs to a device of visibility that regulates the status of the represented bodies and the type of attention they deserve. (Rancière, 2010b, p. 144)

According to Rancière (2006), the politics of aesthetics is always defined by a certain deterritorialization and reorganization of temporalities and given perceptual forms. Thus, an image is political not because it expresses injustice or suffering, but because it reveals how the significant tissue of the sensitive is disturbed, so that individuals, words and objects can no longer be inserted in the sensitive frame defined by a or find their place in the police coordinate system where they are usually located (Marques, 2014).

By highlighting the intertwining of the document and the artistic writing that modulates the visibility and its active counterpart - the invisibility - of the disappeared and murdered women of Júarez, Margolles problematizes the visible gesture claimed by Rancière (2009). The photographs handled in La Búsqueda and Pesquisas are not placed there to compose another discourse on the femicide, but to rescue the lives of these women disappeared from the innumerable registers that increase daily and fill the desks of the police stations or the pages of the newspapers. Finally, it seeks to prolong the search by interrogating the conditions of silence and (in) visibility of so many deaths and disappearances.

In the media spaces of appearances, those who remain faceless, or whose faces are presented as symbols of inferiority or inhumanity, are generally not worthy of recognition. There is violence in the frame of what is shown: certain lives and certain deaths remain unrepresented or represented in order to effect their capture by the machinic effort to carry out the erasure and disappearance through the representation itself.

In what follows, we will try to show that these photographs are not limited to exemplarity, that they are not limited to the illustrative character or even offer a human face to the numerous women disappeared and/or murdered in Juarez; rather, they constitute a "face" (Levinas, 1982; Souza \& Marques, 2016; Biondi \& Marques, 2016).

\section{THE RISING OF THE FACE IN THE PHOTOGRAPH}

The grayish and faded faces in the photographs collected by Margolles resemble what Didi-Huberman (2014) names as "grizzled", that is, the shade of beings and things that, with the passage of time, lose their colors. However, he points out that grayscale images do not present us with anything neutral, stable or strictly defined: it is the joining 
of a moment and a passing movement of time and, when doing so, pulverizes (deposits dust and destroys) the color of things. This action and the power of time to discolor photographs, for example, constitutes a "middle way" between visibility and invisibility, "a gray spot between what changes and what dies" (Didi-Huberman, 2014, p. 7). Thus, the grayish images of Margolles present a latency: discoloration reveals both an absence (a less-being and a non-power) as well as a power associated with the "flesh" of color.

The grizzled is the chromatic representation of temporal and sensory distance. It "consists in offering, in the same atmosphere of discoloration, distance and power, loss of things and the flesh of things, their phenomenal latency" (Didi-Huberman, 2014, p. 17). The erasing material present in the photographs of the disappeared women analyzed here has the power to revive their bodies, since "a gray figure has nothing to do with death, since it can be agitated by a rhythm, a pulsation, an inspiration-expiration movement or of systole-diastole" (Didi-Hubeman, 2014, p. 19).

Levinas (1982) bets on the definition of the face as an expression of the vulnerability of the existent being (as ethical demand addressed to the other), describing its manifestation (apparition) as an experience revealing the living presence and the pure communication of an entity that becomes accessible but not is delivered. Thus, the face is not configured only as what is offered to the vision, but is, above all, as a voice, a clamor that remains in becoming in the incapacitating appearance of the other that is addressed to us.

When you see a nose, the eyes, a forehead, a chin that you can describe, this is what we turn to another as an object. (...) The relationship with the face can undoubtedly be called by perception, but what the face is specifically is what is not reduced to it. (Levinas, 1982, p. 77)

The face, according to Levinas (1982), does not always allow itself to be captured by means of concepts or images; what gives access to the world of the other can not be scrutinized and resists infinitely to our efforts of approximation and appropriation. In a singular approach, Levinas reveals the face as a power of contact with otherness, in an ethical dimension that requires the reception of the other. The face marks, from this perspective, a relationship of openness to another, a form of dialogue in which one does not possess the other, nor does it recognize itself in him either. The face expresses the fact that the other is not a variation of the self and cannot be captured or assimilated by concepts. It can put us before another who challenges us, who suffers, who desires and who invites us to move away from ourselves.

The face does not mean a representative image of the subject, on the contrary, he wants to show his "appearance": therefore he affirms that the face has a visibility that is only perceived by the gaze (a listening eye), in which another person who looks at me is the one who reveals me. The gaze is an integral part of the manifestation and appearance of others. In this sense, the emergence of the face as a still image in the photographs invites us to peer, to look at the face and body of the other, revealing the image as an important support for access to the other and its appearance (Biondi \& Marques, 2016) 5 .

${ }^{5}$ A more detailed discussion on the concept of face in Levinas compared to photographic images of the face of victims can be consulted in Biondi \& Marques, 2016. 
If we are questioned by the other who speaks to us, the face appears as a verb, as a word event, as the possible communication that allows a specific practice of configuring a common world, a polemical world, the fruit of the effort to shape identities and alterities. According to Agamben, "to understand the truth of the face means to take not the resemblance, but the simultaneity of countenances, the restless power that holds them together and brings them together" (2000, p. 94). Therefore, the images of the face can be thought of as the place of the other that becomes the promise of my own place assuming the aesthetic, ethical and political character. We argue that these photographs construct a form of ethical experience with the other: what is exposed is the operative gesture of art, creative fiction, "gesture that draws a common space" (Rancière, 2010b, p. 22).

The face thus alludes to the responsibility of men in the face of the suffering of their fellow men. It is a kind of ethical interpellation addressed to us: we are intimated to an answer, to the welcome of another person totally different from me; we are called to responsibility, not only about what we do, but also about the evil that comes to inflict. Before the face, we are affected in our projects and the self-defense is forever crossed by the imperative "thou shalt not kill" (Levinas, 1999, p. 24), enunciated by the face.

In this respect, Margolles' work responds to the interpellation of the faces that summon us from the faded faces in the photographs: imagine nevertheless not forgetting or being complicit with the horror and violence, but responding to the face that rises from the posters and the photographs. By revealing faces twisted by suffering and marked by the action of time and urban agents, Margolles creates an audiovisual landscape in which echoes an agonizing silent cry. The saying of the face presents us with a sensible dimension that can not be fully embraced by the visible.

Contemplating the face in an image or the face of the image means establishing with it an ethical relationship, a relationship of implication, affectation and interpellation that makes us available to listening, dialogue and reciprocity, establishing a way of welcoming and welcoming the other, without reducing it to "itself": this balance between the approach (opening) and the distance is what constitutes the condition of possibility of any and all forms of communication, of the constitution of sensitive communities.

\section{Final Considerations}

When we return to the question of the singularity and the stereotyping of the faces that emerge in the photograph, it is interesting to reflect on the considerations that Didi-Huberman (2011, p. 67) weaves about the faceless peoples, that is, "the oppressed class, exposed only to disappear or to be underexposed in the consensual representations of history." In this paper, we tried to highlight, through the analysis of the selected images, elements capable of pointing to a type of resistance to the ready life forms, to the erasure and disappearance of the subjects in narratives that only "fit" the individuals in previously architected discursive frames, gestures, routines and bodies in consensual operations, constraints and submissions of all kinds.

In the political movement and through the exposure linked to the "appearing", exposed in Margolles works, individuals become beings with faces, capable of developing 
enunciative and demonstrative capacities to reconfigure the relationship between the visible and the sayable, between words and bodies. Margolles images invite the approach to the other, while ensuring a separation: if it "produces a connection between separate subjects, between subjects of disconnection, it ensures the distance that separates them, preserving them from any identifiable or massifying fusion" (Mondzain, 2011, p. 124). From the notion of face, which is not properly the human face, but a vestige of the presence of an Other, however close it is, remains at a distance. Therefore, it is communication and language, apparition and disappearance, possibility and impossibility of reaching the Other in its infinity (Souza \& Marques, 2016).

The residual life of women presented in Margolles' work expose their condition of vulnerability and precariousness through mechanisms of control and underexposure, leading to social disappearance, impersonality and dehumanization. We can say that through the inquiring and persistent photos of Margolles a micropolitics of resistance can finally arise, reinventing the regimes of enunciation in the image, by the image. The loss of the face is shaped by the process of institutional, discursive and social framing that makes it difficult to listen to the clamor of the other and, thus, the production of ethical responsibility over this fragile and brutalized other.

Through photographs of the faces of these women, Margolles seeks to give them a face: the dignity of the human being is built through a look that listens to the face. She presents us with an exhibition of anonymous women, welcoming them and welcoming the sounds of their suffering through listening and capturing the face. Of course, a photograph does not return the word to the photographed subject. As Didi-Huberman $(2012$, p. 43) points out, the images do not restore their names to people whose faces are exposed. Its purpose is to lift the faces, to support them, to give them the power of faire face. And this, in our view, already means to expose them in the dimension of a possibility of word and of listening.

Translated by Anna Carolina Fagundes Martino

\section{BibLIOGRAPHIC REFERENCES}

Agamben, G. (2000). The face. In G. Agamben, Means without end: notes on politics (pp. 91-100). Minneapolis: University of Minnesota Press.

Biondi, A. \& Marques, A. (2016). Omayra: reflexões sobre o rosto, uma fotografia e suas políticas. Galáxia, 33, 145-157.

Biroli, F. (2016). Autonomia, preferências e assimetria de recursos. Revista Brasileira de Ciências Sociais (RBCS), 31(90), 39-57.

Blay, E. (2008). Assassinato de Mulheres e Direitos Humanos. São Paulo: Editora 34.

Butler, J.; Gambetti, Z. \& Sabsay, L. (2016). Vulnerability in resistance. Duke: Duke University Press.

Butler, J. (2006). Vida precaria. El poder del duelo y da violencia. Buenos Aires: Paidós. 
Butler, J. (2011). Vida precária. Contemporânea. Revista de Sociologia da UFSCar, 1, 13-33.

Butler, J. (2015). Relatar a si mesmo. Belo Horizonte: Autêntica.

Carcedo, A. (2010). No olvidamos niaceptamos: Femicidio en Centroamérica 2000-2006. CEFEMINA. San Jose: Associación Centro Feminista de Información y Acción. Retrieved from http://www.sidocfeminista.org/ images/books/13189/13189_oo.pdf

Caldeira, B. (2017). Entre assassinatos em série e uma série de assassinatos: o tecer da intriga nas construções narrativas de mulheres mortas e seus agressores nas páginas de dois impressos mineiros. Master Dissertation, UFMG-FAFICH, Brazil.

Didi-Huberman, G. (2003). Images malgré tout. Paris: Éditions de Minuit.

Didi-Huberman, G. (2008). La emoción no dice "yo": diez fragmentos sobre la libertad estética. In A. Jaar (Ed.), La política de las imágenes (pp. 39-67). Santiago de Chile: Editorial Metales Pesados.

Didi-Huberman, G. (2011). Sobrevivência dos vaga-lumes. Trad. Vera Casa Nova e Márcia Arbex. Belo Horizonte: Ed. UFMG.

Didi-Huberman, G. (2012). Peuples exposés, peuples figurants: L'Oeil de l'Histoire, 4. Paris: Éditions de Minuit.

Didi-Huberman, G. (2014). Grisalha: poeira e poder do tempo. Lisbon: KKYM + IHA.

Fassin, D. (2007). L'Empire du traumatisme. Enquête sur la condition de victime. Paris: Flammarion.

Fassin, D. (2014). De l'invention du traumatisme à la reconnaissance des victimes. Genèse et transformation d'une condition morale, Vingtième Siècle. Revue d'histoire, 123, 161-171.

Levinas, E. (1999). Alterity and transcendence. New York: Columbia University Press.

Levinas, E. (1982). Ética e infinito. Lisbon: Edições 70.

Levinas, E. (2011). De outro modo que ser ou para lá da essência. Lisbon: Centro de Filosofia da Universidade de Lisboa.

Marques, Â. (2014). Política da imagem, subjetivação e cenas de dissenso. Discursos Fotográficos, 10, 61-86.

Mondzain, M.-J. (2009). A imagem pode matar? Lisbon: Nova Vega.

Mondzain, M.-J. (2011). Nada Tudo Qualquer coisa ou a arte das imagens como poder de transformação. In R. Silva \& L. Nazaré (Eds.), A república por vir. Arte, política e pensamento para o século XXI (pp 103-138). Lisbon: Fundação Calouste Gulbekian.

Picado, J.B. (2014). O olho suspenso do novecento: plasticidade e discursividade visual no fotojornalismo moderno. Rio de Janeiro: Pensamento Brasileiro.

Pignotti, D. (2012, 23 september). Cidade Juarez: um retrato da violência sem fim no México. Carta Maior, Internacional. Retrieved from http://www.cartamaior.com.br/?/Editoria/Internacional/ Cidade-Juarez-um-retrato-da-violencia-sem-fim-no-Mexico/6/25968\#

Rancière, J. (2004). Aux bords du politique. Paris: Gallimard.

Rancière, J. (2006). Le coup double de l'art politisé: entretien avec Gabriel Rockhill. Lignes, 1(19), 141-164.

Rancière, J. (2007). Le travail de l'image. Multitudes, 28, 195-210. 
Rancière, J. (2009). Política de Pedro Costa. In R. M. Cabo (Ed.), Cem Mil Cigarros - os filmes de Pedro Costa (pp. 53-63). Lisbon: Orfeu Negro.

Rancière, J. (2010a). O espectador emancipado. Lisbon: Orfeu Negro.

Rancière, J. (2010b). A estética como política. Revista Devires, 7(2), 14-36.

Rancière, J. (2012). O destino das imagens. Rio de Janeiro: Contraponto.

Russell, D. \& Harmes, R. (2001). Defining femicide and related concepts. In D. Russel \& R. Harmes (Eds.), Femicide in Global Perspective (pp. 12-28). New York: Teacher's College Press.

Souza, F. C. V. \& Marques, A. (2016). Rosto e cena de dissenso: aspectos éticos, estéticos e comunicacionais de constituição do sujeito político. Questões Transversais - Revista de Epistemologias da Comunicação, 4, 17-27.

Tassin, E. (2004). La question de l'apparence. In F. Collin (Ed.), Politique et Pensée: Colloque Hannah Arendt (pp. 69-94). Paris: Éditions Payot \& Rivages.

\section{FinANCial Support}

CAPES - Coordination for the Improvement of Higher Level Personnel; CNPq - National Council for Scientific and Technological Development and FAPEMIG - Foundation for Research Support of Minas Gerais.

\section{BiographicAl Notes}

Ângela Cristina Salgueiro Marques is Professor at the Postgraduate Program in Social Communication, Federal University of Minas Gerais (UFMG). PhD in Social Communication from UFMG and postdoctoral degree from the Université Stendhal, Grenoble III, France. Her current research interests are focused on the intersection between Communication, Politics and Aesthetics; between Communication and Culture, and between communication and political processes, giving priority to minority resistances and daily insurgencies.

E-mail: angelasalgueiro@gmail.com

Rua Castelo de Avis, 193, apto.201, Bairro Castelo. CEP: 31330-110. Belo Horizonte, MG, Brazil

Angie Gomes Biondi is Professor at the Postgraduate Program in Communication and Languages at the Tuiuti University of Paraná (UTP). PhD in Social Communication from UFMG and postdoctoral degree from Université du Québec à Montréal, Canada. Her research interests encompass social and communication processes involving body, image, and sociability articulated with reflection on politics of visibility and contemporary forms of subjectivation.

E-mail: angiebiondina@gmail.com

Travessa Rafael Francisco Greca, 151, apto.153 B. Água Verde. CEP: 80,620-150. Curitiba - Paraná, Brazil 
* Submitted: 31-07-2017

* Accepted: 05-11-2017 